\title{
A Simple and Rapid LC-MS/MS Method for The Determination of BMCL26 A Novel Anti-Parasitic Agent in Rat Plasma
}

\author{
Ramakrishna R. Voggu \\ Cleveland State University \\ Xiang Zhou \\ Cleveland State University, x.zhou34@csuohio.edu \\ Bing Su \\ Cleveland State University, B.SU@csuohio.edu \\ Baochuan Guo \\ Cleveland State University, b.guo@csuohio.edu
}

Follow this and additional works at: https://engagedscholarship.csuohio.edu/scichem_facpub

Part of the Chemistry Commons

How does access to this work benefit you? Let us know!

\section{Recommended Citation}

Voggu, Ramakrishna R.; Zhou, Xiang; Su, Bing; and Guo, Baochuan, "A Simple and Rapid LC-MS/MS

Method for The Determination of BMCL26 A Novel Anti-Parasitic Agent in Rat Plasma" (2015). Chemistry Faculty Publications. 377.

https://engagedscholarship.csuohio.edu/scichem_facpub/377

This Article is brought to you for free and open access by the Chemistry Department at EngagedScholarship@CSU. It has been accepted for inclusion in Chemistry Faculty Publications by an authorized administrator of EngagedScholarship@CSU. For more information, please contact library.es@csuohio.edu. 


\title{
A Simple and Rapid LC-MS/MS Method for the Determination of BMCL26 a Novel Anti-Parasitic Agent in Rat Plasma
}

\section{Ramakrishna R Voggu, Xiang Zhou, Bin Su and Baochuan Guo*}

Department of Chemistry, Cleveland State University, USA

\begin{abstract}
BMCL26 is a potential drug derived from nimesulide, which has exhibited the substantial anti-parasitic activity in various cell lines. To conduct various pharmacological and toxicological properties of this drug, we developed and validated a rapid LC-MS/MS method for its quantification in accordance with the FDA guidelines. Protein precipitation with $0.1 \%$ formic acid in acetonitrile was used to extract the analytes along with the internal standard (JCC76) from rat plasma. It was found that the calibration curve of the method had an excellent linearity $\left(r^{2} \geq 0.9993\right)$ for the analyte concentration ranging from 0.5 to $100 \mathrm{ng} / \mathrm{mL}$ with acceptable inter- and intra-assay, precision, accuracy and stability. The matrix effect and extraction recovery were in the range of $101.30-110.10 \%$ and $90.16-105.00 \%$, respectively. This LC-MS/MS method is simple and rapid and can be used in the future pharmaceutical studies of BMCL26.
\end{abstract}

Keywords: BMCL26; Anti-parasitic; LC-MS/MS; Protein precipitation; Rat plasma

\section{Abbreviations}

\%CV: Coefficient of Variation; IS: Internal Standard; LLOQ: Lower Limit Of Quantification; MRM: Multiple Reaction Monitoring; AMP: Aminoprophos-Methyl; JCC76: N-(3-(2,5-dimethylbenzyloxy)-4(methylmethylsulfonamido)phenyl)cyclohexanecaboxamide; \%RE: Relative Error; RME: Relative Matrix Effect; QC: Quality Control; SD: Standard Deviation

\section{Introduction}

Human African trypanosomiasis, also known as sleeping sickness, is a vector-borne parasitic disease and a serious health threat to a large number of people living in sub-Saharan Africa, where health systems are challenged at best [1-3]. Trypanosoma brucei gambiense (T. $b$. gambiense) and Trypanosoma brucei rhodesiense (T. b. rhodesiense) are the etiological parasites that cause sleeping sickness in humans. These parasites live and grow extracellularly in the blood and tissue fluids of humans or cattle and are transmitted among hosts by tsetse flies (Glossina spp.). Without effective treatment, the disease can lead to coma and ultimately death. If the patients do not receive treatment in a timely manner, the neurological damage caused by these parasites is irreversible even after treatment [3,4]. Current drugs used to treat human trypanosomiasis include Suramin, Pentamidine, Melarsoprol and Eflornithine [5], however, these drugs do not effectively treat the disease, maintaining an urgent need for new, more effective and less expensive drugs for the treatment of human African trypanosomiasis [4-6].

Tubulin is a very attractive target in the field of anti-cancer drug discovery, and several successful tubulin binders are used clinically as first-line chemotherapeutic agents [7]. Tubulin also plays an essential role during trypanosome cell division. The fast, populationdoubling rate of trypanosomes makes them highly dependent on tubulin polymerization/depolymerization [8]. More importantly, tubulin is critical for trypanosome locomotion, which is essential for trypanosomes survival. Tubulin inhibitors not only block T. brucei cell division but also affect the locomotive functions of flagellum and lead to cell death [9]. Some microtubule-disrupting herbicides, such as phosphoric thioamide herbicide Amiprophos-Methyl (APM) and dinitroaniline herbicides, exhibit activity against protozoan parasites by targeting tubulin [10-14]. Research works have optimized these compounds, generating more potent and selective tubulin inhibitors for
T. brucei [10]. Webovertz's group successfully developed several drug candidates that show promising anti-parasite activity and selectivity in vitro. However, these compounds did not show substantial potency in vivo due to their poor stability [15].

Recently, we have developed a class of tubulin inhibitors as anti-cancer agents $[16,17]$. These compounds share the same core scaffold and bind to a colchicine-binding domain on tubulin [16]. We performed $T$. brucei cell-growth inhibition assays with our compounds, some of which exhibited very specific inhibitory effects on $T$. brucei growth resulting in selectivity indices $\left(\mathrm{IC}_{50}\right.$ inhibiting human cancer cell growth/ $/ \mathrm{IC}_{50}$ inhibiting $T$. brucei cell growth) of 5 or more. Among these compounds, BMCL26 has been identified as a potential drug candidate. BMCL26 exhibited activity against T. brucei cell proliferation with an IC50 of $1.62 \mu \mathrm{M}$ but inhibited mammalian cell growth with an $\mathrm{IC}_{50}$ of $55.35 \mu \mathrm{M}$ [18]. The selective index of BMCL26 is approximately 34 , and its $\mathrm{IC}_{50}$ (for inhibiting $T$. brucei proliferation) is in the low micromolar range, which is obtainable in blood. The present investigation addresses the critical need of developing a method to accurately quantify BMCL26 concentrations in blood. Thus, in this paper, we report the development and validation of a robust and highly sensitive LC-MS/MS method for quantitating BMCL26 in rat plasma with an LLOQ of $0.5 \mathrm{ng} / \mathrm{mL}$ and a linear calibration range of up to 100 $\mathrm{ng} / \mathrm{mL}$.

\section{Experimental}

\section{Chemicals and reagents}

BMCL26 and JCC76 (internal standard) were synthesized and purified according to previously published procedures $[18,19]$.

*Corresponding author: Baochuan Guo, Department of Chemistry, College of Science and Health Professions, Cleveland State University, 2121 Euclid Avenue, Cleveland, Ohio, 44115, USA, Tel: 216-687-9219; Fax: 216-687-9298; E-mail: B.GUO@csuohio.edu

Received July 24, 2015; Accepted August 08, 2015; Published August 15, 2015

Citation: Voggu RR, Zhou X, Su B, Guo B (2015) A Simple and Rapid LC-MS/ MS Method for the Determination of BMCL26 a Novel Anti-Parasitic Agent in Rat Plasma. J Anal Bioanal Tech 6: 265 doi:10.4172/2155-9872.1000266

Copyright: (c) 2015 Voggu RR, et al. This is an open-access article distributed under the terms of the Creative Commons Attribution License, which permits unrestricted use, distribution, and reproduction in any medium, provided the original author and source are credited. 
Methanol (HPLC grade) and acetonitrile were from Pharmco-Apper (Philadelphia, Pennsylvania, USA). Formic acid and ammonium acetate (analytical grade) were purchased from Sigma Aldrich Chemical Company (Allentown, Pennsylvania, USA). Deionized water was obtained using a Barnstead Nano pure water purification system with a Nanopure Diamond Pack Organic free DI cartridge from Thermo Scientific (Waltham, Massachusetts, USA). Six individual lots of rat plasma (Sprague-Dawley rat plasmas K2) were obtained from Innovative Research (Novi, Michigan, USA) (Figure 1).

\section{Calibration standards and quality-control samples}

Preparation of stock and working solutions: A set of BMCL26 working solutions containing 10, 20, 50, 150, 400, 1000 and $2000 \mathrm{ng} /$ $\mathrm{mL}$ were prepared by serial dilution using methanol and $1 \mathrm{mg} / \mathrm{mL}$ stock solution. The $150 \mathrm{ng} / \mathrm{mL}$ working solution of JCC76 (IS) was diluted from a stock solution of $1 \mathrm{mg} / \mathrm{mL}$ in methanol. Stock solutions and working solutions were stored at $-20^{\circ} \mathrm{C}$ and $4^{\circ} \mathrm{C}$.

\section{Calibration and preparation of quality-control (QC) plasma samples}

Calibration plasma samples were prepared by spiking $10 \mu \mathrm{l}$ of corresponding BMCL26 working solutions in $200 \mu$ of rat plasma (mixture of 6 lots) with drug concentrations of 0.5, 1.0, 2.5, 5, 12.5, 25, 50 , and $100 \mathrm{ng} / \mathrm{mL}$. QC samples at three concentrations, 1.25 (low), 10 (mid) and 80 (high) ng/mL, were prepared by adding $10 \mu \mathrm{L}$ of the appropriate BMCL26 working solution and $200 \mu \mathrm{L}$ of drug-free plasma. Calibration and QC samples were frozen at $-20^{\circ} \mathrm{C}$ overnight and then treated using the following sample preparation procedure before LCMS/MS analysis.

\section{Sample extraction}

QC samples and blanks were removed from the $-20^{\circ} \mathrm{C}$ freezer and thawed to room temperature. Ten $\mu$ of JCC76 working solution were spiked into each $200 \mu \mathrm{L}$ aliquot of plasma calibrators/QCs/blanks, excepting the double blank, into which $10 \mu \mathrm{L}$ of acetonitrile was added. The solutions were then vortexed immediately for $30 \mathrm{sec}$, after which each sample was deproteinized by adding $800 \mu \mathrm{l}$ of $0.1 \%$ formic acid in acetonitrile, sonicating for 15 minutes, and centrifuging at 13,000 $\times \mathrm{g}$ for 15 minutes. The supernatants were then transferred into auto sampler vials for LC-MS/MS analysis.

\section{LC-MS/MS analysis}

LC-MS/MS analysis was performed using a 5500 Q-TRAP triple quadrupole, tandem mass spectrometer (AB Sciex, Toronto, Canada) coupled with an Electrospray Ionizer (ESI) operated in negative ion mode (Framingham, Massachusetts, USA) and interfaced with High Performance Liquid Chromatography (HPLC, Shimadzu, Columbia, Maryland, USA) system that uses auto-sampling and online vacuum degassing. All data acquisition and processing were conducted using Analyst software, version 1.5.2 (AB Sciex).

Analytical separation of BMCL26 was achieved using a Luna C8 (2) HPLC column $(50 \times 2.0 \mathrm{~mm}, 5$ micron $)$ with a C8 security-guard cartridge from Phenomenex (Torrance, California, USA). Mobile phase A contained $50 \mu \mathrm{M}$ ammonium acetate in $2 \%$ Methanol, and mobile phase B contained $50 \mu \mathrm{M}$ ammonium acetate in $90 \%$ Methanol. Sample aliquots of $5 \mu$ l were injected onto the column and eluted via the following gradient flow: 0-0.6 min, 70\% B, $1.6 \mathrm{~min}, 90 \%$ B, $7.5 \mathrm{~min}$, and stop (Table 1). The column was equilibrated for 0.5 min before each run. Negative electrospray ionization (ESI) mode was selected, and the MRM (multiple reaction monitoring) function was used for quantification, with the transitions set at $\mathrm{m} / \mathrm{z} 573.3$ $\rightarrow 493.2$ for BMCL26 and $\mathrm{m} / \mathrm{z} 443.2 \rightarrow 79.1$ for JCC76 (IS) (Figure $2)$, respectively. The following ion-source-dependent parameters were used: nebulization gas (30), heating gas (30), curtain gas (35), ion spray voltage $(-4330 \mathrm{ev})$ and temperature $\left(500^{\circ} \mathrm{C}\right)$. Compounddependent parameters were manually optimized as follows: declustering potential, -40; entrance potential, -10; collision energy and cell exit potential for both analyte and internal standard, -30 , $-100,-13$, and -9 .

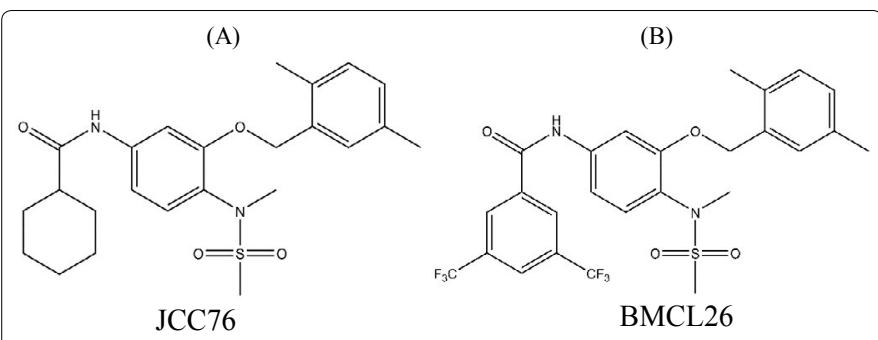

Figure 1: The chemical structures of JCC76 (A), internal standard BMCL26 (B).

\begin{tabular}{|c|c|c|}
\hline Minutes & Event & Parameters \\
\hline $0-0.6$ & $\mathrm{~B} \%$ & 70 (isocratic) \\
\hline $0.6-1.6$ & $\mathrm{~B} \%$ & $70-90$ (liner) \\
\hline $0-3.5$ & Total flow & $0.25 \mathrm{ml} / \mathrm{min}$ \\
\hline $3.5-3.7$ & Total flow & $0.25-0.6 \mathrm{ml} / \mathrm{min}$ \\
\hline $1.6-5.5$ & $\mathrm{~B} \%$ & 90 (isocratic) \\
\hline $5.5-5.6$ & $\mathrm{~B} \%$ & $90-70$ (liner) \\
\hline $3.5-5.9$ & Total flow & $0.6 \mathrm{ml} / \mathrm{min}$ \\
\hline $5.9-6.0$ & Total flow & $0.25-0.6 \mathrm{ml} / \mathrm{min}$ \\
\hline $5.6-7.5$ & B $\%$ & 70 (liner) \\
\hline
\end{tabular}

Table 1: HPLC gradient program.

(A)

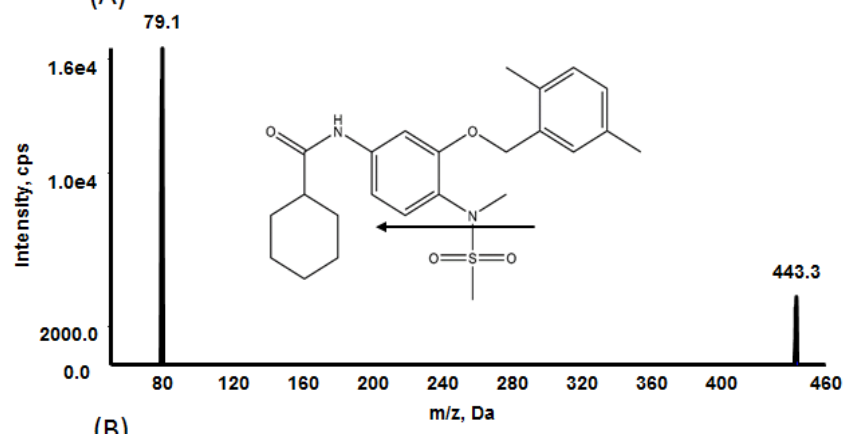

(B)

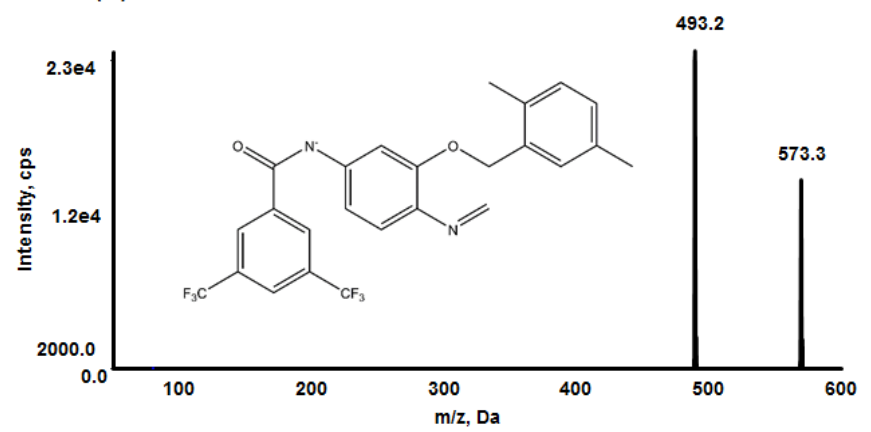

Figure 2: Precursor/product ion spectra and proposed fragmentation pathways for internal standard JCC76 (A) and analyte BMCL26 (B). 


\section{Analytical method validation}

The LC-MS/MS assay was fully validated according to the Food and Drug Administration (FDA) Bioanalytical Method Guidelines [20] and other references [21-23]. The entire assay was validated for linearity, accuracy, precision, selectivity, extraction recovery, matrix effect and stability.

\section{Linearity and calibration}

Eight concentrations of BMCL26 $(0.5,1.0,2.5,5,12.5,25,50$, and $100 \mathrm{ng} / \mathrm{mL}$ ) were selected for the plasma calibration curve $(\mathrm{n}=2$ for each of the eight calibrators, average for each calibrator plotted). A weighed linear regression, using $1 / x$ as the weighing factor, was used to calculate the slope and correlation coefficient of the calibration curve.

\section{Accuracy and precision}

To determine the intra- and inter-day accuracy and precision of the assay, we tested five replicates of BMCL26 at the LQC, MQC, and HQC using $1.25,10$ and $80 \mathrm{ng} / \mathrm{mL}$. Intra-assay and inter-assay precisions were defined as Relative Standard Deviations (RSD) between replicate measurements. Accuracies were calculated using the following formula: accuracy $(\%)=($ experimental concentration - spiked concentration)/ (spiked concentration) $\times 100$. The criteria for data acceptability included accuracy and precisions within $\pm 15 \%$ of the nominal value and the RSD.

\section{Extraction recovery and matrix effects}

The extraction recoveries and matrix effects of BMCL26 for three concentrations of QC samples (low, $1.25 \mathrm{ng} / \mathrm{mL}$; medium, $10 \mathrm{ng} /$ $\mathrm{mL}$; and high, $80 \mathrm{ng} / \mathrm{mL}$ ) were determined by comparing peak areas of analyte-spiked plasma aliquots before extraction to peak areas of analyte-spiked solutions extracted from blank plasma and comparing the response of solutions spiked with analyte after extraction to the response of analyte dissolved in the mobile phase.

\section{Stability studies}

The stabilities of BMCL26 in rat plasma samples were determined using two distinct QC standards (1.25 and $80 \mathrm{ng} / \mathrm{mL})$, which were tested after 8 hours at room temperature and after two months at $-20^{\circ} \mathrm{C}$; freeze-thaw stabilities were determined using three freeze-thaw cycles over a three day period. Short-term stabilities were also determined for post-preparation QC standards stored at room temperature for 10 hours. The QC results obtained after storage were compared with spiked concentration values by determining the percentage ratios of experimental values divided by spiked values.

The stabilities of stock and working solutions for both analyte and internal standard were also evaluated. Stock solutions of analyte and IS were stored at $-20^{\circ} \mathrm{C}$ for 9 months. From both stored and fresh stock solutions, two QC standards $(1.25$ and $80 \mathrm{ng} / \mathrm{mL})$ were prepared for the analyte, to which $7.5 \mathrm{ng} / \mathrm{mL}$ IS (JCC76) was added, and the experimentally determined concentrations of BMCL26 and JCC76 were compared ( $\mathrm{n}=3$ for each).

\section{Results and Discussion}

\section{Optimization of mass spectrometric conditions for quantitation}

The negative ionization mode was selected for both BMCL26 and JCC76 (IS) detection in this study because the analyte produced a much stronger signal for negative ionization compared to positive ionization.
It was found that analyte and IS solutions prepared in methanol-water $(9: 1, \mathrm{v} / \mathrm{v})$ yielded stronger signals compared to solutions prepared in acetonitrile-water $(9: 1, \mathrm{v} / \mathrm{v})$. Adding ammonium acetate to the methanol-water solution substantially increased BMCL26 signals. Therefore, a gradient flow of methanol-water-ammonium acetate was chosen for the HPLC mobile phase. Figure 2 showed the parent ion spectra for both BMCL26 and IS. The highest fragment-ion signals were obtained by fine-tuning the collision energy, spray voltage, and ion source temperature. Based on our ionization and fragmentation optimization results, we chose MRM transitions of $\mathrm{m} / \mathrm{z} 573.2 \rightarrow 493.2$ for BMCL26 and $443.2 \rightarrow 79.1$ for IS for quantification, as these product ions yielded strong and stable signals.

\section{Optimization of HPLC conditions}

The gradient flow of the mobile phase, which was used with different flow rates, was as follows: A: $50 \mu \mathrm{M}$ ammonium acetate in $2 \%$ methanol and mobile phase; B: $50 \mu \mathrm{M}$ ammonium acetate in $90 \%$ methanol (Table 1). Because the C-18 column had a carry-over problem with BMCL26, a C-8 column was used instead. The C-8 column effectively resolved the carryover problem and also yielded a better peak shape. Thus, BMCL26 and IS were separated using a C-8 column with a flow rate of $0.25 \mathrm{~mL} /$ min for $3.5 \mathrm{~min}$, after which the flow rate was increased to $0.6 \mathrm{~mL} /$ min for column clean up and re-equilibration. Retention times were observed at $2.51 \mathrm{~min}$ for BMCL26 and $3.14 \mathrm{~min}$ for IS (Figure 3). The total run time was $8 \mathrm{~min}$.

\section{Linearity, sensitivity, selectivity and LLOQ}

Using the concentrations of BMCL26 in the working solutions, plasma calibration curves were constructed over a concentration range
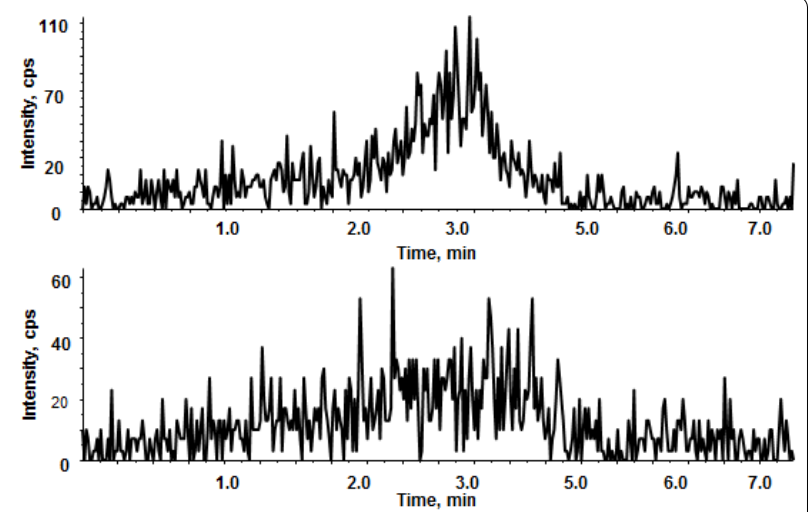

(B)
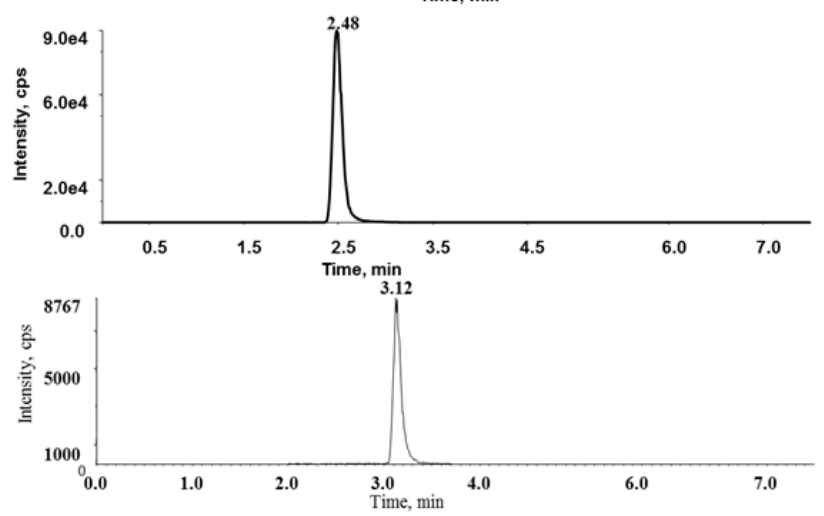

Figure 3: (A) MRM chromatograms of blank rat plasma in both IS and Analyte windows (B) IS JCC76 (10 ng/ml, $3.12 \mathrm{~min})$ and BMCL26 at LLOQ level (0.5 $\mathrm{ng} / \mathrm{ml}, 2.48 \mathrm{~min}$ ). 
Citation: Voggu RR, Zhou X, Su B, Guo B (2015) A Simple and Rapid LC-MS/MS Method for the Determination of BMCL26 a Novel Anti-Parasitic Agent in Rat Plasma. J Anal Bioanal Tech 6: 265 doi:10.4172/2155-9872.1000266

Page 4 of 5

of $0.5-100 \mathrm{ng} / \mathrm{mL}$. Linearity results showed a quadratic fit for BMCL26 using an eight-point calibration curve $(0.5,1,2.5,5,12.5,25,50$, and 100 $\mathrm{ng} / \mathrm{mL})$ with JCC76 $(7.5 \mathrm{ng} / \mathrm{mL})$ as the internal standard in the plasma samples. Excellent linearity was obtained with a correlation coefficient $\left(\mathrm{r}^{2}\right)$ of 0.9993 . The linear regression equation was $\mathrm{y}=0.073 \mathrm{x}-0.0085$. This method exhibited high selectivity and displayed no interfering peaks in six different blank plasma samples from different sources. Using the calibration curve, the LLOQ of the method was determined to be 0.5 $\mathrm{ng} / \mathrm{mL}$. The accuracy and precision were determined for each lot of plasma at the LLOQ. The data were summarized in Table 2.

\section{Accuracy and precision}

Intra- and inter-assay accuracies (\%RE) and precisions (\%CV) were evaluated by analyzing five replicates of low, medium, and high QC standards. As summarized in Table 3, the assay's intra- and interday relative errors were 0.62 and $11.36 \%$, respectively, and the assay's intra- and inter-day precisions were $0.84-3.47 \%$, respectively. These values were within acceptable limits according to FDA guidelines.

\section{Extraction recovery and matrix effects}

It was found that protein precipitation was a good way to extract BMCL26 from plasma. Initially, we used $80 \%$ acetonitrile to precipitate plasma proteins, but a strong matrix effect was observed. Consequently, we utilized pure acetonitrile to precipitate proteins with $0.1 \%$ formic acid (for deproteinization). The latter precipitation conditions eliminated the matrix effect and achieved symmetrical chromatographic peak shapes. The absolute and relative extraction recoveries were in the range of $90.16-105.00 \%$. The results were summarized in Table 4. As shown in Table 5, the absolute and relative matrix effects of BMCL26 from six different rat plasma samples at three QC concentrations (low $(1.25 \mathrm{ng} / \mathrm{mL})$, medium $(10 \mathrm{ng} / \mathrm{mL})$, and high $(80 \mathrm{ng} / \mathrm{mL})$ ranged from $101.30-110.10 \%$.

\section{Stability}

The stability of BMCL26 was determined by comparing the mean peak area ratios of BMCL26 to IS in low $(1.25 \mathrm{ng} / \mathrm{mL})$ and high $(80 \mathrm{ng} /$

\begin{tabular}{|c|c|c|c|}
\hline Nominal Concentration $\mathbf{( n g / m L )}$ & Determined Concentration (ng/mL) & Accuracy (\%RE) \\
\hline 0.5 & $0.47 \pm 0.03$ & -7.46 \\
\hline 1 & $0.99 \pm 0.02$ & -0.22 \\
\hline 2.5 & $2.54 \pm 0.05$ & 1.40 \\
\hline 5 & $5.14 \pm 0.27$ & 2.80 \\
\hline 12.5 & $12.75 \pm 0.31$ & 2.00 \\
\hline 25 & $25.27 \pm 0.73$ & 1.08 \\
\hline 50 & $51.03 \pm 0.97$ & 2.01 \\
\hline 100 & $98.26 \pm 0.99$ & -1.74 \\
\hline
\end{tabular}

Table 2: Accuracy and precision of BMCL26 calibration standards in rat plasma ( $n=5$, pooled plasma samples).

\begin{tabular}{|c|c|c|c|c|c|c|c|c|}
\hline \multicolumn{5}{|c|}{ Intra-assay } & \multicolumn{4}{|c|}{ Inter-assay } \\
\hline Normal (ng/ml) & Determined (ng/ml) & Accuracy (\%RE) & SD & Precision (\%CV) & Determined (ng/ml) & Accuracy (\%RE) & SD & Precision (\%CV) \\
\hline 1.25 & 1.20 & 11.36 & 0.02 & 1.72 & 1.36 & 9.12 & 0.04 & 3.38 \\
\hline 10 & 10.20 & 2.00 & 0.16 & 1.64 & 10.20 & 2.00 & 0.35 & 3.43 \\
\hline 80 & 80.70 & 0.87 & 0.68 & 0.84 & 80.50 & 0.62 & 2.80 & 3.47 \\
\hline
\end{tabular}

Table 3: Inter and intra-assay accuracy and precision of BMCL26 in rat plasma.

\begin{tabular}{|c|}
\hline Concentration of $\mathbf{Q C}$ samples$(\mathbf{n g} / \mathbf{m l})$ \\
\hline 1.25 \\
10 \\
80 \\
\hline
\end{tabular}

\begin{tabular}{|l|l|}
\hline Absolute & \\
\hline Mean extraction recovery & $\% \mathbf{C V}$ \\
\hline $104.00 \pm 4.89$ & 4.70 \\
\hline $105.00 \pm 4.99$ & 4.75 \\
\hline $96.30 \pm 3.00$ & 3.12 \\
\hline
\end{tabular}

\begin{tabular}{|l|l|}
\hline Relative & \\
\hline Mean extraction recovery & $\%$ CV \\
\hline $98.10 \pm 9.73$ & 9.92 \\
\hline $95.96 \pm 3.61$ & 3.76 \\
\hline $90.16 \pm 2.87$ & 3.18 \\
\hline
\end{tabular}

Table 4: Absolute and relative Extraction recovery of BMCL26 in rat plasma.

\begin{tabular}{|c|l|l|l|l|}
\hline Concentration of QC samples $(\mathbf{n g} / \mathbf{m l})$ & Absolute & \multicolumn{2}{l|}{ Relative } \\
\hline & Mean matrix effect & \%CV & Mean matrix effect \\
\hline 1.25 & $105.00 \pm 1.07$ & 1.02 & $108.00 \pm 5.15$ \\
\hline 10 & $107.00 \pm 6.06$ & 5.66 & $110.10 \pm 8.99$ \\
\hline 80 & $105.00 \pm 3.86$ & 3.68 & $101.30 \pm 4.78$ \\
\hline
\end{tabular}

Table 5: Absolute and relative matrix effect of BMCL26 in rat plasma.

\begin{tabular}{|c|c|c|}
\hline Storage conditions & Concentration $(\mathbf{n g} / \mathbf{m l})$ & Recovery $\%$ \\
\hline Bench top $(8 \mathrm{hr})$ & 1.25 & 103.46 \\
\hline At room temp & 80.00 & 103.20 \\
\hline Freeze thaw (3 cycles) & 1.25 & 98.13 \\
\hline Post extraction & 80.00 & 105.20 \\
\hline$(10 \mathrm{hr})$ at room temp & 1.25 & 101.86 \\
\hline
\end{tabular}

Table 6: Stability of BMCL26 in plasma samples. 
Citation: Voggu RR, Zhou X, Su B, Guo B (2015) A Simple and Rapid LC-MS/MS Method for the Determination of BMCL26 a Novel Anti-Parasitic Agent in Rat Plasma. J Anal Bioanal Tech 6: 265 doi:10.4172/2155-9872.1000266

$\mathrm{mL}$ ) QC samples to those of freshly prepared QC solutions (containing the same concentrations), expressed in terms of recovery. As shown in Table 6, the receives of LQC and HQC samples were 103.46-103.20\%, 98.13-105.20\%, and 101.86-107.54\% for bench top conditions, after 3 freeze-thaw cycles and post extraction at room temperature for 10 hours, respectively. The stabilities of working solutions of BMCL26 and internal standard (JCC76), stored at $4^{\circ} \mathrm{C}$ for at least 6 months, were determined to be $99.60-105.00 \%$ and $115.60 \%$ for the two QC standards tested (1.25 and $80 \mathrm{ng} / \mathrm{mL}$ ), to which $7.5 \mathrm{ng} / \mathrm{mL}$ IS was added (using the stored stock solution). These stability results showed no significant deviations in BMCL26 quantification under the experimental conditions used.

\section{Conclusion}

This innovative method offers several advantages for assaying BMCL26 in rat plasma including simplicity, cost effectiveness, accuracy and precision were below $11 \%$ and $3 \%$, with high sensitivity and selectivity. To our knowledge, this is the first time this method was used. This assay employed a simple protein precipitation procedure for plasma sample preparation. The LLOQ was as low as $0.5 \mathrm{ng} / \mathrm{mL}$. The results from the validation study illustrated that this method can be used to determine the pharmacological and toxicological profiles of BMCL26 in rats in the future.

\section{Acknowledgements}

The authors acknowledge the following sources of support for this work: NIH grant R15AI 103889 (B. Su) and the National Science Foundation Major Research Instrumentation Grant (CHE-0923398).

\section{References}

1. Barrett MP (2006) The rise and fall of sleeping sickness. Lancet 367: 1377-1378.

2. Barrett MP, Burchmore RJ, Stich A, Lazzari JO, Frasch AC, et al. (2003) The trypanosomiases. Lancet 362: 1469-1480.

3. Brun R, Blum J, Chappuis F, Burri C (2010) Human African trypanosomiasis Lancet 375: 148-159.

4. Frankish $\mathrm{H}$ (2003) Initiative launched to develop drugs for neglected diseases. Lancet 362: 135.

5. Steverding D, Tyler KM (2005) Novel antitrypanosomal agents. Expert Opin Investig Drugs 14: 939-955.

6. Issa VS, Bocchi EA (2010) Antitrypanosomal agents: treatment or threat? Lancet 376: 768

7. Kuppens IE (2006) Current state of the art of new tubulin inhibitors in the clinic. Curr Clin Pharmacol 1: 57-70.

8. Werbovetz KA (2002) Tubulin as an antiprotozoal drug target. Mini Rev Med Chem 2: 519-529.
9. Okuno M, Asai DJ, Ogawa K, Brokaw CJ (1981) Effects of antibodies against dynein and tubulin on the stiffness of flagellar axonemes. J Cell Biol 91: 689-694.

10. Werbovetz KA, Sackett DL, Delfín D, Bhattacharya G, Salem M, et al (2003) Selective antimicrotubule activity of N1-phenyl-3,5-dinitro-N4,N4-di-npropylsulfanilamide (GB-II-5) against kinetoplastid parasites. Mol Pharmacol 64: $1325-1333$

11. Benbow JW, Bernberg EL, Korda A, Mead JR (1998) Synthesis and evaluation of dinitroanilines for treatment of cryptosporidiosis. Antimicrob Agents Chemother 42: 339-343.

12. Morejohn LC, Fosket DE (1984) Inhibition of Plant Microtubule Polymerization in vitro by the Phosphoric Amide Herbicide Amiprophos-Methyl. Science 224 874-876.

13. Murthy JV, Kim HH, Hanesworth VR, Hugdahl JD, Morejohn LC (1994) Competitive Inhibition of High-Affinity Oryzalin Binding to Plant Tubulin by the Phosphoric Amide Herbicide Amiprophos-Methyl. Plant Physiol 105: 309-320.

14. Dawson PJ, Gutteridge WE, Gull K (1984) A comparison of the interaction of anthelmintic benzimidazoles with tubulin isolated from mammalian tissue and the parasitic nematode Ascaridia galli. Biochem Pharmacol 33: 1069-1074.

15. Wu D, George TG, Hurh E, Werbovetz KA, Dalton JT (2006) Pre-systemic metabolism prevents in vivo antikinetoplastid activity of $\mathrm{N}, \mathrm{N} 4-$ substituted 3,5-dinitro sulfanilamide, GB-II-150. Life Sci 79: 1081-1093.

16. Yi X, Zhong B, Smith KM, Geldenhuys WJ, Feng Y, et al. (2012) Identification of a class of novel tubulin inhibitors. J Med Chem 55: 3425-3435.

17. Zhong B, Cai X, Chennamaneni S, Yi X, Liu L, et al. (2012) From COX-2 inhibitor nimesulide to potent anti-cancer agent: synthesis, in vitro, in vivo and pharmacokinetic evaluation. Eur J Med Chem 47: 432-444.

18. Lama R, Sandhu R, Zhong B, Li B, Su B (2012) Identification of selective tubulin inhibitors as potential anti-trypanosomal agents. Bioorg Med Chem Lett 22: 5508-5516.

19. Suleyman H, Halici Z, Cadirci E, Hacimuftuoglu A, Bilen H (2008) Indirect role of beta2-adrenergic receptors in the mechanism of anti-inflammatory action of NSAIDS. J Physiol Pharmacol 59: 661-672.

20. Gao L, Li J, Kasserra C, Song Q, Arjomand A, et al. (2011) Precision and accuracy in the quantitative analysis of biological samples by accelerator mass spectrometry: application in microdose absolute bioavailability studies. Anal Chem 83: 5607-5616.

21. Cai X, Zhong B, Su B, Xu S, Guo B (2012) Development and validation of rapid LC-MS/MS method for the determination of JCC76, a novel antitumor agent for breast cancer, in rat plasma and its application to a pharmacokinetics study. Biomed Chromatogr 26: 1118-1124.

22. Ye Feng, Kunos CA, Yan Xu (2015) Determination of Triapine, a Ribonucleotide Reductase Inhibitor, in Human Plasma by Liquid Chromatography Tandem Mass Spectrometry (LC-MS/MS). Biomed Chromatogr 29: 1380-1387.

23. Voggu RR, Alagandula R, Zhou X, Su B, Zhong B, et al. (2015) A rapid LC-MS MS method for quantification of $\mathrm{CSUOH} 090$, a novel antitumor agent, in rat plasma. Biomed Chromatogr 29: 797-802.

OMICS International: Publication Benefits \& Features Unique features:

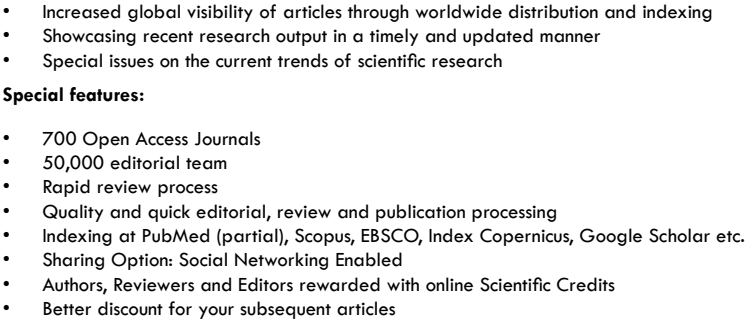

MS Method for the Determination of BMCL 26 a Novel Anti-Parasitic Agent in Rat Plasma. J Anal Bioanal Tech 6: 265 doi:10.4172/2155-9872.1000266 